\title{
Bioremediation of Mercury through Encapsulation of the Clone Carrying meroperon
}

\author{
Gaurav Jaiswal, Rajni Singh and Shalini Porwal* \\ Amity Institute of Microbial Biotechnology, Amity University, Sector-125, Noida - 201 303, India.
}

\begin{abstract}
Mercury $(\mathrm{Hg})$ being one the most toxic element on the earth and its capability to result in neurotoxic disorder has become a serious problem for human health and environmental issues. Methyl mercury is the organic form of the mercury which easily accumulates within the aquatic animals and led to biomagnification in other higher organisms. $\mathrm{Hg}$ in the environment is resulted from unregulated discharge of mercury within the environment via numerous industries. Hence, it is crucial to bioconvert the toxic form of mercury to non-toxic form with the useful resource of microbes. One of the pronounced site of mercury contamination reported in India (Panipat) containing $147 \mathrm{ppm} \mathrm{Hg}$ content, was selected to construct metagenomic library of mer operon using E.coli as host. The clone showed maximum tolerance towards mercury $(90 \mathrm{ppm})$ accompanied through effective volatilization $(91.89 \%$ to $41.23 \%)$ for $\mathrm{Hg}(10-90 \mathrm{ppm})$. The clone was able to efficiently bio-convert $\mathrm{Hg}$ in actual contaminated site as well. It was also encapsulated in sodium alginate beads and polyacrylamide gel in order to test its reusability for conversion of $\mathrm{Hg}$.
\end{abstract}

Keywords: Mercury, mer operon, CV-AAS, sodium alginate bead, polyacrylamide gel entrapment.

\footnotetext{
*Correspondence: sporwal@amity.edu; 91120-4392900
}

(Received: 05 January 2019; accepted: 22 February 2019)

Citation: Gaurav Jaiswal, Rajni Singh and Shalini Porwal, Bioremediation of Mercury through Encapsulation of The Clone Carrying meroperon, J Pure App/ Microbiol., 2019; 13(1):553-560 doi: 10.22207/JPAM.13.1.62

(c) The Author(s) 2019. Open Access. This article is distributed under the terms of the Creative Commons Attribution 4.0 International License which permits unrestricted use, sharing, distribution, and reproduction in any medium, provided you give appropriate credit to the original author(s) and the source, provide a link to the Creative Commons license, and indicate if changes were made. 


\section{INTRODUCTION}

The outflow of industrial effluents has been always the cause of environmental concern as they pollute rivers and lands by adding up the toxic element and harmful metals. Among various heavy metals, mercury is known as a lethal metal which is positioned on 6th number in toxicity ${ }^{1}$. The unregulated discharge of mercury from industries and other human interventions has led to widespread of various neurological diseases ${ }^{2}$. The continuous and prolonged exposure to mercury may be source of fatigue, neurasthenia, numbness in toes and fingers, clumsiness, inability to cognizance, hearing to and visual disabilities, acute bronchitis, intestinal pneumonitis ${ }^{3}$. The worst case is followed by coma and death. Biomagnification of mercury in each trophic level has become a major cause of health risks at each level as it has entered the food chain through bio-accumulation. The level of mercury has been found to increase by 20-100 or even more folds than its permissible limit as the result of the unregulated and uncontrolled discharge of mercury ${ }^{4}$.

Increase in mercury pollution attracted the attention of some scientist to encounter the problem and they came up with the most widely used technique of bioremediation which uses microbes to convert toxic metals to less toxic form. This inquisitiveness of scientist helped them to discover microbes that can effectively grow well in the presence of mercury. Scientist discovered the sets of the genes which were responsible for providing resistant to such a toxic metal and called it as mercury (mer) operon ${ }^{4}$. Further researches confirm the presence of this operon on transposons element, conjugative plasmid and chromosomes which confers the bacteria with ability to survive mercury contamination and also confers the antibiotic resistance towards some antibiotics ${ }^{5,6}$.

The indigenous researches on mer operon has discovered two major genes which are mainly responsible for mercury conversion in bacteria are merA and merB genes. Where merB genes encodes methylmercury lyase which convert organic form of mercury $\left(\mathrm{CH}_{3} \mathrm{Hg}^{2+}\right)$ to $\mathrm{Hg}^{2+}$ and merA gene code for mercury reductase which converts inorganic form of mercury $\left(\mathrm{Hg}^{2+)}\right.$ to nontoxic risky form $\left(\mathrm{Hg}^{\circ}\right)$. Other genes of mer operon have been also found which are equally important for transportation of $\mathrm{Hg}$ within the system ${ }^{7}$.

This study was undertaken to clone the mer operon derived through metagenomics. The metagenome from the sample was isolated and the desired fragment (mer operon) was cloned in E.coli. The clone was checked for its ability to convert toxic form of $\mathrm{Hg}$ to non-toxic form in $\mathrm{Hg}$ contaminated site (Panipat Soil Sample). The clone was also immobilized to examine its reusability for the same.

\section{MATERIALS AND METHODS}

\section{Sample collection and mer operon library} construction

Panipat industrial area was selected for soil sample collection because it is reported to have much higher concentration of mercury than the permissible limit. The soil was taken $10 \mathrm{~cm}$ under the ground level by digging it and was kept in sterile container at $4^{\circ} \mathrm{C}$ for further investigation.

In order to determine the concentration of mercury present in the soil sample, $10 \mathrm{gm}$ of sample was weighed to check $\mathrm{Hg}$ concentration present in the soil using CV-AAS.

MOBIO kit was used to isolate metagenomic DNA from the soil sample following the protocol provided by the manufacturer. Before constructing the library the DNA was quantified using UV-absorption at $260 \mathrm{~nm}$ at dilution fold of 500. After the quantification the partial restriction digestion was performed to get the desired fragment size of 5 to $10 \mathrm{~Kb}$ in order to make clones.

For restriction digestion reaction, sterile micro-centrifuge tube was used to set up the reaction of $150 \mu$ l which consist of $100 \mu$ l of DNA, $15 \mu$ l of 10X enzyme buffer, $1.5 \mu$ l of Sau $3 \mathrm{~A} 1$ and $33.5 \mu \mathrm{l}$ autoclave distilled water. The reaction was setup in the ice bucket and immediately transferred to $16^{\circ} \mathrm{C}$ for $3 \mathrm{~h}$. The reaction was terminated by heating the mixture at $70^{\circ} \mathrm{C}$ in water bath. The digested metagenomic DNA was run on $1 \%$ Agarose using gel electrophoresis assembly (BIORAD) and the fragments of the DNA in range of 5-10Kb were gel eluted using HiYield Gel/PCR DNA Mini Kit (Real Biotech Corporation, Taiwan). Ligation reaction was setup using digested DNA and dephosphorylated $p U C 19$ vector digested with $\mathrm{Bam} \mathrm{HI}$ along with T4 DNA ligase enzyme. The mixture was incubated at $4^{\circ} \mathrm{C}$ for $16-18 \mathrm{~h}$ and reaction was terminated by heat inactivation of 
enzyme at $70^{\circ} \mathrm{C}$. Electroporation at $200 \mathrm{~W}, 25 \mathrm{mF}$ and $2.5 \mathrm{kV}$ was done by introducing recombinant vector into host bacteria (E.coli DH10B) with aid of Micropulser II (BIO RAD). Immediately, the tube was poured with $1 \mathrm{ml}$ of Luria Broth (LB) and kept in shaker incubator at $180 \mathrm{rpm}$ for $1 \mathrm{~h}$. Transformed cells $(100 \mu \mathrm{l})$ were spread on the Luria Bertani Agar (LBA) plates supplemented with ampicillin, X-gal and IPTG and incubated at $37^{\circ} \mathrm{C}$ for $16 \mathrm{~h}$.

Screening and selection of mercury resistant clones

The white colonies were picked and streaked on the LBA plates which were supplemented with ampicillin and $5 \mathrm{ppm}$ of Mercury Chloride $\left(\mathrm{HgCl}_{2}\right)$, incubated at $37^{\circ} \mathrm{C}$ for 24-48h. The clones which were able to grow in the presence of $5 \mathrm{ppm}$ of $\mathrm{HgCl}_{2}$ were transferred to fresh LB supplemented with $10 \mathrm{ppm}$ of $\mathrm{HgCl}_{2}$. The clones showing visible growth at $10 \mathrm{ppm}$ were further transferred to $20 \mathrm{ppm}, 30 \mathrm{ppm}$ and so on up to $100 \mathrm{pm}$ for acclimatization of clones and examined by taking OD at $600 \mathrm{~nm}$. The clone which showed maximum growth after acclimatization at highest $\mathrm{HgCl}_{2}$ concentration was selected for further studies. To check the presence of merB gene, the clone was grown in LB with $5 \mathrm{ppm}$ and 10ppm of Methyl Mercury Chloride $\left(\mathrm{CH}_{3} \mathrm{HgCl}_{2}\right)$, incubated at $37^{\circ} \mathrm{C}$ for $18 \mathrm{~h}$ and $\mathrm{OD}$ was taken at 600nm.

\section{Antibiotics resistance assay}

Antibiotic resistance of the selected clone was checked through disk diffusion method against various antibiotic listed in Table 1 . Freshly cultured clone was spread on the LBA plates and antibiotic discs were placed onto it, incubated at $37^{\circ} \mathrm{C}$ for 18h. Later, zone of inhibition was measured.

Investigation of $\mathrm{Hg}$ volatilization by $\mathrm{CV}$-AAS

The clone was inoculated in LB media

Table 1. Antibiotics used for antibiotic resistance activity.

\begin{tabular}{lll}
\hline $\begin{array}{l}\text { S. } \\
\text { No. }\end{array}$ & Antibiotic & $\begin{array}{r}\text { Concentration } \\
\text { (mcg) }\end{array}$ \\
\hline 1 & Streptomycin & 25 \\
2 & Norflaxin & 10 \\
3 & Tetracyclin & 30 \\
4 & Vancomycin & 30 \\
5 & Gentamycin & 30 \\
6 & Kanamycin & 30
\end{tabular}

containing 10 to $100 \mathrm{ppm}$ of $\mathrm{HgCl}_{2}$ and incubated at $37^{\circ} \mathrm{C} ; 180 \mathrm{rpm}$. The culture was drawn periodically on $2^{\text {nd }}, 4^{\text {th }}$ and $6^{\text {th }}$ day under sterile conditions in tubes and centrifuged at 8000rpm for 8 mins. The supernatant was used for CV-AAS analysis (Analytical Jena make (Vario-6) cold vapor Hg-AAS). In-vivo efficacy of the clone for $\mathrm{Hg}$ Volatilization

The Panipat soil (non-sterile) was taken and mixed with the sterile soil to make $5 \mathrm{~kg}$ of mixture of around 10ppm $\mathrm{Hg}$ concentration (3:2) wt/wt). Overnight grown culture $(500 \mathrm{ml}) ;(10 D)$ was sprayed onto the soil mixture. The soil sample was periodically taken out on $2^{\text {nd }}, 4^{\text {th }}$ and $6^{\text {th }}$ day. The samples were used for CV-AAS in order to check the ability of clone to transform the toxic $\mathrm{Hg}$ to non-toxic form on the contaminated site. Entrapment of clone to check its repeatability Immobilization was done to check the efficiency of the clone to convert the $\mathrm{Hg}$ from toxic form to non-toxic form of mercury by repeated use. Two methods were used for immobilization listed below (3 cycles).

\section{Sodium alginate Entrapment method}

Pre-grown culture (16h) was mixed with sodium alginate $(3 \% \mathrm{w} / \mathrm{v})$ in the ratio of $1: 4$ and mixed well to make slurry under sterile conditions. The slurry was added to $0.2 \mathrm{M}$ of Calcium Chloride $\left(\mathrm{CaCl}_{2}\right)$ drop-wise using sterile tips at room temperature in laminar air flow. Then the beads were stored at $4^{\circ} \mathrm{C}$ for $1 \mathrm{~h}$. After cooling the beads were washed 2-3 times with autoclaved distilled water and inoculated in conical flask containing $30 \mathrm{ml}$ of LB supplemented with 10, 20 and 30ppm of $\mathrm{HgCl}_{2}$ respectively. The flasks were incubated at $37^{\circ} \mathrm{C} ; 180 \mathrm{rpm}$ and beads were drawn the time interval of $24 \mathrm{~h}$ (for 3 days). The beads were washed and re-inoculated to LB having same concentration of $\mathrm{HgCl}_{2}$. This procedure was repeated thrice to check reusability of entrapped clone. CV-AAS of drawn samples at different time intervals were done.

\section{Polyacrylamide gel entrapment method}

Cell suspension of pre-grown culture (16h) was prepared by adding $2 \mathrm{ml}$ of culture into $10 \mathrm{ml}$ of chilled autoclaved distilled water and kept aside. $10 \mathrm{ml}$ of the Potassium Phosphate Buffer (pH 7.0, 0.2M) was prepared, Acrylamide (2.85g), Bis-acrylamide $(0.15 \mathrm{~g})$, Ammonium persulphate (10mg) and TEMED (1ml) were added to the buffer. The chilled cell suspension was mixed with 
polyacrylamide gel and poured into a sterile petri plate for solidification. After solidification, the cubes ( $5 \mathrm{~mm} \times 5 \mathrm{~mm} \times 5 \mathrm{~mm}$ ) were cut using sterile scalpel and kept in Sodium Phosphate Buffer $(\mathrm{pH}$ $7.0,0.2 \mathrm{M}$ ) for $1 \mathrm{~h}$ at $4^{\circ} \mathrm{C}$. The cubes were washed 3-4 times and put into conical flask containing LB $(30 \mathrm{ml})$ supplemented with 10, 20 and $30 \mathrm{ppm}$ of $\mathrm{HgCl}_{2}$. The flasks were incubated at $180 \mathrm{rpm}, 37^{\circ} \mathrm{C}$ and cubes were drawn each day after $24 \mathrm{~h}$ (for 3 days). The cubes were washed and re-inoculated to $\mathrm{LB}$ having same concentration of $\mathrm{HgCl}_{2}$. The drawn samples were used for CV-AAS analysis.

\section{RESULT AND DISCUSSION Metagenomic library construction}

Panipat soil sample was estimated for its Hg content by CV-AAS which was observed to be around $147 \mathrm{ppm}$ that's 14700 folds higher than the permissible limit i.e. $0.01 \mathrm{mg} / \mathrm{ml}$ for industrial effluents ${ }^{8}$.

The DNA isolated from Panipat industrial soil had the concentration of $500 \mathrm{ng} / \mu \mathrm{l}$ at the absorbance of 260nm (Fig. 1). Metagenome was digested using Sau3A1. The desired DNA fragment in the range of $5-10 \mathrm{~Kb}$ was cut and gel eluted. The DNA obtained after elution was ligated to

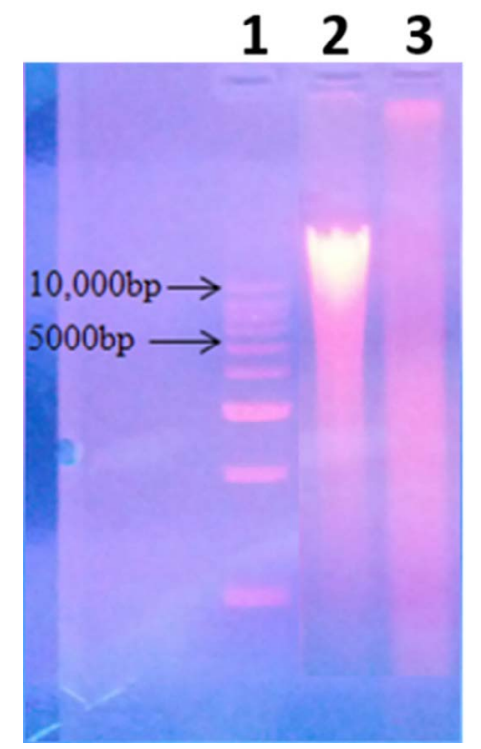

Fig. 1. Lane 1: $10 \mathrm{~kb}$ DNA ladder, 2: Metagenomic DNA (Panipat) \& 3: Metagenomic DNA Restricted digested with Sau3A1 dephosphorylated pUC 19 vector predigested with Bam HI.

Approximately 200 clones were streaked on LBA plates supplemented with $5 \mathrm{ppm}$ of $\mathrm{HgCl}_{2}$, only 120 were able to grow among them.

\section{Selection of the mercury resistant clone}

The clones which were able to grow on $5 \mathrm{ppm}$ were transferred to $10 \mathrm{ppm} \mathrm{Hg}$ concentration, and only 74 clones showed visible growth. Further with increase in concentration of $\mathrm{Hg}$ to $50 \mathrm{ppm}$, steep decrease was seen among the selected clones (Table 2 ) and only 5 clones (P02, P15, P27, P58 and P98) were able to grow.

The clones which were able to grow at $50 \mathrm{ppm}$ of $\mathrm{Hg}$ had been chosen for acclimatization, by growing and transferring them to higher concentration of $\mathrm{Hg}$ (10ppm to $100 \mathrm{ppm})$. Among five, chosen clones only one (P02) was able to

Table 2. Numbers of clones shown growth at different $\mathrm{Hg}$ concentration

\begin{tabular}{lcc}
\hline S.No & $\begin{array}{c}\text { Concentration } \\
\text { of } \mathrm{HgCl}_{2}\end{array}$ & $\begin{array}{c}\text { Number of } \\
\text { tolerant clones }\end{array}$ \\
\hline 1 & 05 & 120 \\
2 & 10 & 74 \\
3 & 20 & 33 \\
4 & 30 & 14 \\
5 & 40 & 5 \\
6 & 50 & 5 \\
7 & 60 & - \\
8 & 70 & - \\
\hline
\end{tabular}

Table 3. Acclimatization of clones at different $\mathrm{Hg}$ Concentration.

\begin{tabular}{lclllll}
\hline S. & Mercury & & & & & \\
No. & $\begin{array}{c}\text { Chloride } \\
\text { Conc. }(p p m)\end{array}$ & P02 & P15 & P27 & P58 & P98 \\
\hline
\end{tabular}

\begin{tabular}{lcccccc}
\hline 1 & 10 & + & + & + & + & + \\
2 & 20 & + & + & + & + & + \\
3 & 30 & + & + & + & + & + \\
4 & 40 & + & + & + & + & + \\
5 & 50 & + & + & + & + & + \\
6 & 60 & + & - & - & + & - \\
7 & 70 & + & - & - & - & - \\
8 & 80 & + & - & - & - & - \\
9 & 90 & + & - & - & - & - \\
10 & 100 & - & - & - & - & - \\
\hline
\end{tabular}

(+) showing growth of clone; (-) no growth. 
grow at 90ppm and beyond it no growth was seen (Table 3). Hence P02 clone was selected for further studies.

\section{Antibiotic resistant activity}

Upon research of $\mathrm{P} 02$ for antibiotic resistance activity using disc diffusion method the zone of inhibition was measured (mm) (Fig. 2). P02 has shown resistant towards Tetracyclin (30 mcg) and Vancomycin $(30 \mathrm{mcg}$ ), whereas showed the susceptibility towards Norflaxin (10 mcg) and
Gentamycin (30 mcg). The microbes found to be mercury resistant are often antibiotic resistant ${ }^{[5]}$ which is result of horizontal gene transfer ${ }^{7}$.

CV-AAS of $\mathrm{Hg}$ volatilization

Volatilization analysis was done to quantify the amount of $\mathrm{Hg}$ converted to non-toxic form in media. The volatilization was found to be maximum on $6^{\text {th }}$ day at $10 \mathrm{ppm}$ (91.89\%), however it was $89 \%$ on $4^{\text {th }}$ day and $87.37 \%$ on $2^{\text {nd }}$ day. Gradual increase in volatilization was seen on $2^{\text {nd }}$

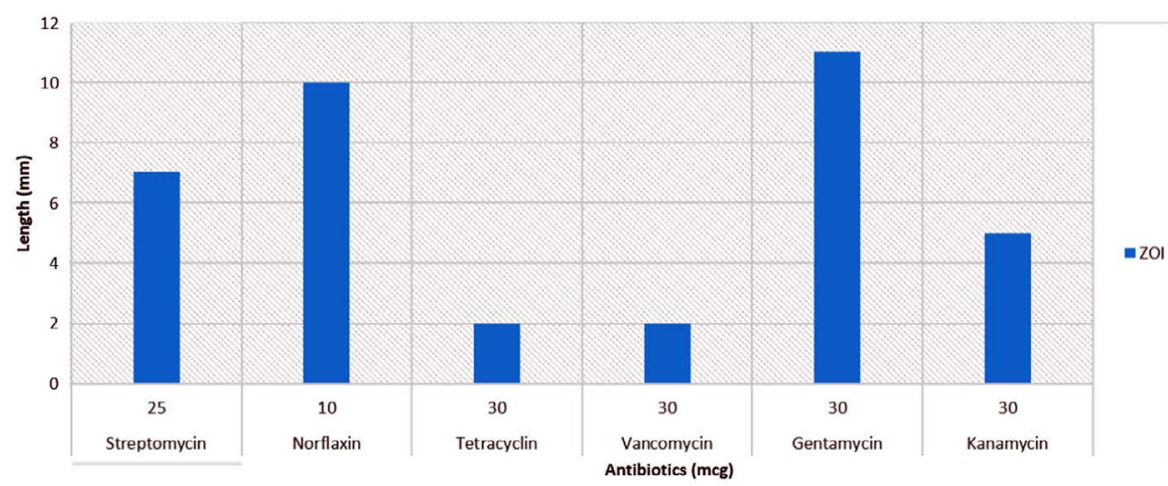

Fig. 2. Antibiotic resistance of P02 clone.

*Resistant (0-4mm), Intermediate (5-8mm) and Susceptible $(9-12 \mathrm{~mm}) ; \mathrm{ZOI}=$ zone of inhibition

day $(37.05 \%), 4^{\text {th }}$ day $(39.46 \%)$ and $6^{\text {th }}$ day $(41.23 \%)$ at $90 \mathrm{ppm}$ (Fig. 3). The volatilization efficiency of P02 is more as compared to the volatilization by isolates as reported ${ }^{9,10}$

Efficiency of volatilization by clone on soil In order to check the functionality of P02 on mercury contaminated soil this study was undertaken and the results showed that P02 was efficient in conversion of $\mathrm{Hg}^{2+}$ to $\mathrm{Hg}^{\circ}$. 10ppm of concentration was chosen for soil as it showed maximum volatilization in media. The volatilization was checked on $2^{\text {nd }}, 4^{\text {th }}$ and $6^{\text {th }}$ day and maximum was found to be on $6^{\text {th }}$ day which was about $91.87 \%$ as compared to 4 th day and 2 nd day, which was calculated to be around $85.97 \%$ and $80.37 \%$ respectively (Fig. 4). The volatilization of $\mathrm{Hg}$ was more on mercury contaminated soil as compared to only media $(\mathrm{LB}+\mathrm{Hg})$ may be due to autochthonic bacteria which might have increased the volatilization.

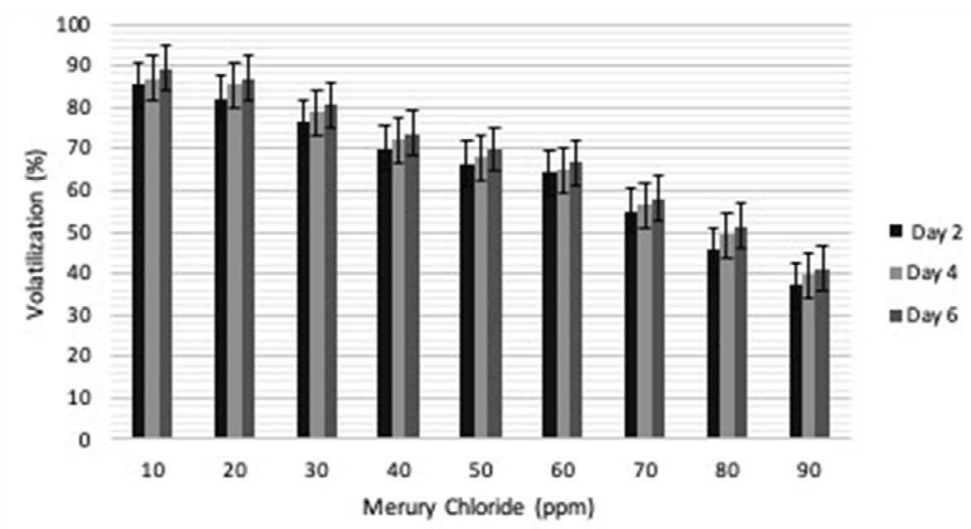

Fig. 3. Volatilization (\%) of $\mathrm{HgCl}_{2}$ by $\mathrm{PO2}$ in nutrient media $\left(\mathrm{LB}+\mathrm{HgCl}_{2}\right)$. 


\section{Entrapment of clone and its reusability}

Reusability of clone P02 was checked by its immobilization by two methods i.e. sodium alginate and polyacrylamide. CV-AAS analysis of supernatant showed more volatilization at low level of $\mathrm{Hg}$ concentration in both the cases.
The results also revealed volatilization of $\mathrm{Hg}$ (10-30ppm) was more with clone immobilized in sodium alginate (cycle 1: 84.88 to $49.53 \%$; cycle 2: 37.5 to $31.76 \%$; cycle 3 : 21.82 to $18.5 \%$ ) as compared to immobilization in polyacrylamide (cycle 1: 60.83 to $40.41 \%$; cycle 2: 42.5 to $37 \%$;

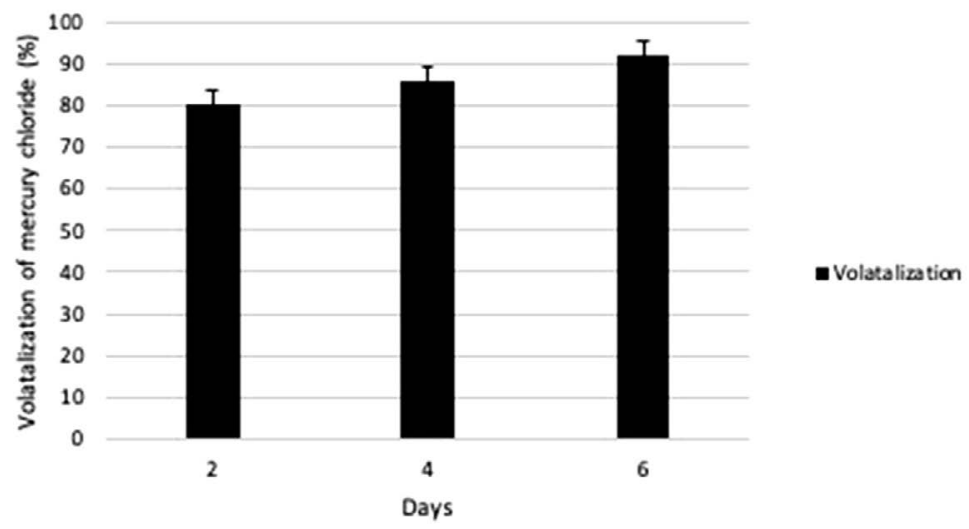

Fig. 4. Volatilization (\%) of $\mathrm{HgCl}_{2}$ in soil (Panipat)

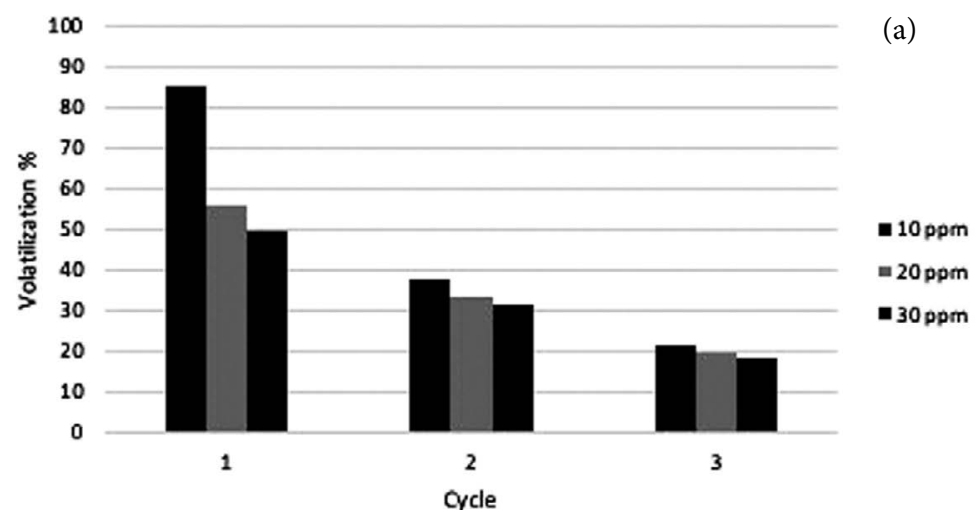

(b)

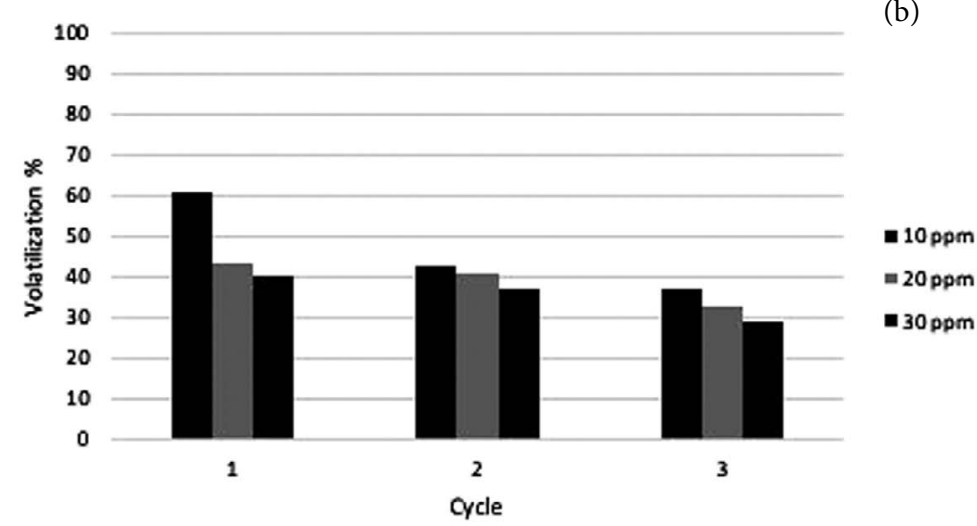

Fig. 5. Volatilization of $\mathrm{Hg}$ by PO2 immobilized in : (a) Sodium alginate (b) Polyacrylamide gel. 
cycle 3: 37.1 to $29.1 \%$ ).

Though the volatilization in cycle 1 was more in case of sodium alginate but the reusability of clone was found to be more in polyacrylamide entrapment (Fig. 5a \& 5b).

\section{DISCUSSION}

Numerous uses of mercury have brought about the enormous human health problem as it is one of the most toxic heavy metal found in the environment ${ }^{13}$. In order to triumph over the toxicity, some microbes have developed the mechanism to transform the toxic compound to non-toxic compound which gave perception of bioremediation. Many studies supported that microbes can convert toxic mercury to non-toxic form ${ }^{14}$.

Most of the microbes cannot be culture in lab but lives in the environment and contribute toward the bioremediation of mercury if present in their habitat ${ }^{3}$. In our study P02 was found to convert both form of $\mathrm{Hg}$ i.e. $\mathrm{CH}_{3} \mathrm{HgCl}_{2}$ (organic) to $\mathrm{HgCl}_{2}$ (inorganic) and finally to its non-toxic volatile form $\left(\mathrm{Hg}^{\circ}\right)$, hence the clone have the broad spectrum mechanism of $\mathrm{Hg}$ tolerance. It has been found that antibiotic resistant genes are commonly found on the plasmid or the transposons carrying $\mathrm{Hg}^{\mathrm{r}}$ loci ${ }^{11}$ which may be transferred through horizontal gene transfer on the conjugative plasmid. $\mathrm{P} 02$ have shown antibiotic resistant property toward tetracyclin $(30 \mathrm{mcg})$ and vancomycin (30 $\mathrm{mcg}$ ) along with the resistance to mercury. The mechanism of mercury resistance for both the form (organic and inorganic) was primarily studied on Staphy-lococcus aureus a clinical isolate which was also found to be resistance to antibiotic called penicillin ${ }^{4}$. It was observed that the maximum volatilization of $\mathrm{Hg}$ (10-90ppm) in media ( $\mathrm{LB}+\mathrm{Hg}$ ) happened on day 2 (87.37\%-37.05\%), whereas almost complete conversion happened on day 6 (91.89\%-41.23\%) which was the added volati-lization $\%$ of the residual $\mathrm{Hg}$ after day 2. The application study results indicated that the volatilization of P02 was much more effective in $\mathrm{Hg}$ contaminated soil $(80.34 \%, 85.97 \%$ and $91.87 \%$ on day 2,4 \& 6 respectively) at 10ppm, which may be due to the activity of autochthonic microbes which has escalate the process of volatilization. We have also observed that polyacrylamide gel entrapped P02 clones were more efficient for reusability than the sodium acrylamide and can be effectively used for $\mathrm{Hg}$ bioremediation, as supported by other studies $^{12}$.

In this study clone P02 has confirmed maximum tolerance $(90 \mathrm{ppm})$ of $\mathrm{Hg}$ with the efficiency of volatilizing it to vapor form in LB media. The volatilization turned more visible in actual mercury-contaminated soil than the LB media. Clones may be immobilized in polyacrylamide gel and used time and again for $\mathrm{Hg}$ conversion efficiently ${ }^{15-17}$.

\section{ACKNOWLEDGEMENTS}

We are thankful to Department of Science and Technology, Government of India, for providing the funds to carry out the study and also thankful to Amity University, Sector-125, Noida, UP, for providing infrastructure and Dr. Rakesh Sharma, IGIB, New Delhi, Dr. Nahar Singh, NPL, Delhi for their help and support.

\section{CONFLICT OF INTEREST}

The authors declare that there are no conflicts of interest.

\section{REFERENCES}

1. Barkay T, Miller S M, Summers A O. Bacterial mercury resistance from atoms to eco-systems. FEMS microbiol. Rev., 2003; 27(2-3): 355-384.

2. Woods J S, Heyer N J, Russo J E, Martin M D,Farin F M. Genetic polymorphisms affecting suscep-tibility to mercury neurotoxicity in children: Summary findings from the Casa Pia Children's Amalgam. Clinical Trial Neurotoxicology, 2014; 44: 288-302.

3. Mathema V B,Thakuri B C,\&Sillanpה M. Bacterial mer operon-mediated detoxification of mercurial compounds: a short review. ArchMicrobiol, 2011; 193(12): 837-844.

4. Jaiswal G, Porwal S. Role of mercury resistance (mer) operon in bioremediation of mercury contamination. J. BioChem. Res., 2014; 2: 986-997.

5. Porwal S, Singh R. Cloning of merA Gene from MethyloteneraMobilis for Mercury Bio-transformation. Indian J. Microbiol, 2016; 56(4): 504-507.

6. McArthur J V,Tuckfield R C. Spatial patterns in antibiotic resistance among stream bacteria: effects of industrial pollution. Appl Environ Microbiol., 2000; 66(9): 3722-6.

7. Sant'ana YX,Chartone-Souza E, Ferreira MD. Drug resistance and colicinogeny of Salmonella typhimurium strains isolated from sevrage-contamined surface water and humans in Belo Horizonte, Brazil.Revista Microbiol., 1989; 20(1): 41-9.

8. Nascimento A M,Chartone-Souza E. Operon mer: bacterial resistance to mercury and potential for 
bioremediation of contaminated environments. Genetics Mol. Res., 2003; 2(1): 92-101.

9. Mercury pollution of India, Centre for Science and Environment. http://www.cseindia.org/node/439. Accessed 20 September 2017

10. MahbubK R, Krishnan K, Naidu R,Megharaj M. Mercury resistance and volatilization by Pseudoxanthomonas sp. SE1 isolated from soil. Environ. Technol. Inno., 2016; 6: 94-104.

11. Sathiyanarayanan G,Saibaba G, Kiran GS, Yang YH, Selvin J. Marine sponge-associated bacteria as a potential source for polyhydroxyalkanoates. Crit Rev Microbiol., 2017; 43(3): 294-312.

12. Wireman J, Liebert CA, Smith T, Summers AO. Association of mercury resistance with antibiotic resistance in the gram-negative fecal bacteria of primates. Appl Environ Microbiol., 1997; 63(11): 4494503.

13. Ashraf W. Levels of selected heavy metals in tuna fish. Arabia J. Sci. Eng., 2006; 31(1A): 89.
14. Bilal $M$,Asgher $M, \& M N$ Iqbal $H$. Polyacrylamide gel-entrapped fungal manganese peroxidase from Ganoderma lucidum IBL-05 with enhanced catalytic, stability, and reusability charac-teristics. Protein and peptide letters, 2016; 23(9): 812-818.

15. Wang $X$, He Z, Luo $H$, Zhang $M$, Zhang D, Pan $X, \&$ Gadd GM. Multiple-pathway remediation of mercury contamination by a versatile selenite-reducing bacterium. SciTotal Environ., 2018; 615: 615-623.

16. Kane AL, Al-Shayeb B,Holec PV,Rajan S, Le Mieux NE, Heinsch SC, Psarska S, Aukema KG, Sarkar CA,Nater EA,Gralnick JA. Toward bioremediation of methylmercury using silica encapsulated Escherichia coli harboring the mer operon. PloS one, 2016; 11(1): e0147036.

17. Sinha A,Khare SK. Mercury bioremediation by mercury accumulating Enterobacter sp. cells and its alginate immobilized application. Bio-degradation, 2012; 23(1): 25-34. 